\title{
The study of crime and its relation to the development
}

\section{Studi tentang kejahatan dan hubungannya dengan pembangunan}

\author{
Elvi Zuriyani* \& Rika Despica \\ Department of Geography Education, STKIP PGRI Sumatera Barat \\ Address: Jalan Gunung Pangilun, Padang, West Sumatera 25111 \\ E-mail: pephy.ez@gmail.com
}

\begin{abstract}
This study discusses the crimes that have occurred in Padang city and their relationship with the development of the city itself. This study used a descriptive spatial approach. The data on crime obtained from Pos Metro Padang newspaper, which specifically contains criminal news from 2015-2016. The data on the development of Padang city was taken from a literature study using a Central Bureau of Statistics or Badan Pusat Statistik (BPS) report. The study used indicators such as the economic level of the region, population data, population density, regional infrastructure, and any linkages with other regions. The results of this study involved the dominant crimes in Padang city of theft, illegal drugs, and immorality. The results showed that there were six sub-districts with high crime rates in 2015 and 2016, including West Padang, South Padang, Lubuk Begalung, Kuranji, East Padang, and Koto Tangah. West Padang and South Padang are downtown areas with high levels of economic activity. East Padang, Lubuk Begalung, Kuranji, and Koto Tangah are the suburban areas of Padang, which also have high population density levels. These areas focused around an education center in Padang City. Based on the results, there is a link between the development of the region and criminal activity. With the presence of various activities in the downtown area, densely populated people and the large number of activities that take place in suburban areas will result in the emergence of various attractions that makes people interested in coming to the region. It is also one of the factors that can trigger criminal acts in Padang city.
\end{abstract}

Keywords: crime; development; urban area

\begin{abstract}
Abstrak
Penelitian ini membahas tentang kejahatan yang telah terjadi di kota Padang dan hubungannya dengan perkembangan kota itu sendiri. Penelitian ini menggunakan pendekatan deskriptif spasial. Data kejahatan diperoleh dari surat kabar Pos Metro Padang yang secara khusus memuat berita kriminal dari 2015-2016. Data perkembangan kota Padang diambil dari studi literatur menggunakan laporan Badan Pusat Statistik (BPS). Studi ini menggunakan indikator seperti tingkat ekonomi suatu wilayah, data populasi, kepadatan penduduk, infrastruktur daerah, dan hubungan apa pun dengan daerah lain. Hasil penelitian ini melibatkan kejahatan dominan di kota Padang pencurian, obat-obatan terlarang dan amoralitas. Hasil penelitian menunjukkan bahwa ada enam kecamatan dengan tingkat kejahatan tinggi pada tahun 2015 dan 2016 termasuk Padang Barat, Padang Selatan, Lubuk Begalung, Kuranji, Padang Timur dan Koto Tangah. West Padang dan South Padang adalah daerah pusat kota dengan aktivitas ekonomi tingkat tinggi. Padang Timur, Lubuk Begalung, Kuranji, dan Koto Tangah adalah daerah pinggiran kota Padang yang juga memiliki tingkat kepadatan pendudukyang tinggi. Wilayah-wilayah ini difokuskan di sekitar pusat pendidikan di Kota Padang. Berdasarkan hasil penelitian ini, ada hubungan antara pengembangan wilayah dan kegiatan kriminal. Dengan hadirnya berbagai kegiatan di kawasan pusat kota, penduduk yang padat dan banyaknya kegiatan yang berlangsung di kawasan pinggiran kota akan mengakibatkan munculnya berbagai objek wisata yang membuat orang tertarik datang ke wilayah tersebut. Ini juga salah satu faktor yang bisa memicu tindak kriminal di kota Padang.
\end{abstract}

Kata kunci: tindak kriminalitas; perkembangan; kawasan perkotaan

\section{Introduction}

Crime is a social problem that can happen anywhere, one of which is in urban areas. Urban areas are areas where the main activity is non-agricultural or where $75 \%$ of the people have not got a livelihood that is that of a farmer. The other criteria for urban areas are for it to have a minimum population of 10.000 inhabitants with a population density of at least 50 inhabitants/ha. These areas serve as a regional urban residential center, as a center of the economy and as a focal point of the education and administration centers present. 
As the provincial capital of West Sumatra, the Padang administration area amounted to $694,96 \mathrm{~km}$. Meanwhile, according to Law Number 10 of 2005, the area of Padang is $1414,96 \mathrm{~km}^{2}$, with the addition of areas of water totaling $720 \mathrm{~km}^{2}$. The Padang city administration consists of 11 districts and 104 villages (Badan Pusat Statistik 2016a). As the provincial capital, the economic activities, administration, and other services based in Padang City. It affects the population movement from or to Padang City. Various activities happen in Padang City, whether they are economic, social, educationrelated, etc. Urban areas must not be separated from the various social problems present, one of which is a crime. According to Yuliandarmaji (2013), the area cannot be separated from the social problems that arise, one of which is the crime problem. Yuliandarmaji (2013) revealed that the opportunity to be a thief presented as becoming a person with free will, involving the decision to practice hedonism and the failure to perform the appropriate social traits. It incurs a penalty that imposed on the perpetrator. Poverty affects the crime rate. Kartono (1999) in Koranti (2014) stated that the incidence of criminal acts caused by the biological-sociological factor composed of economic factors (the whole economy, population, changes in market prices, financial crisis, unemployment), mental factors (religion, literature, and film), physical factors (the climate) and personal factors (age, race, alcohol, and war).

According to the crime statistics in West Sumatra, there have been 16.277 criminal cases (Badan Pusat Statistik 2015). Meanwhile, in Padang itself, based on the data from Badan Pusat Statistik (BPS) Padang city in 2016, 7.627 acts of criminality occurred in 2014. In 2015, there were 7.853 criminal acts, and in 2016, the criminal acts totaled as many as 7.554. It can be seen that the level of crime increased in 2015 but decreased in 2016. However, generally in the jurisdiction of West Sumatra, there has been an increase in crime every year from 2000 to 2015. It can be caused by many things, one of which is related to the development of the city and the population growth that occurred within the urban areas. Based on the background that has been presented, the purpose of this study was to determine the relationship of crime occurring with urban areas, especially in Padang City. The data obtained in this research based on the type of crime that occurred and the location of the crime. The data obtained on both the crime and on the location of the occurrence. The data were then classified based on the crime that took place in each district of Padang City. It followed by the analysis related to the development of each region in Padang City.

\section{Research methods}

This type of research is descriptive. According to Punaji (2010), descriptive research is a research study that aims to explain or describe a situation, event, or object, and whether it involves people. Anything related to the variable can be explained through either numbers or words. In this research, the data collection technique used was the documentation technique. The data collection was related to the different types of crimes that occur. The spatial analysis technique involved the data that had been collected and then grouped and analyzed using separately spatial-mapped analysis - the documents about the incident obtained from the media crime section of Metro Padang Post newspaper.

According to Sugiyono (2013), a document is a record of events that have passed, inclusive of different forms of writing, drawing, or monumental works. Examples of such documents include diaries, the history of life (life histories), stories, biographies, regulations, and policies. Other documents may include images, photographs, motion pictures, and sketches. It can include works of art in the form of pictures, sculptures, or films. In this research, the focus of the research and data that observed and collected in this study a crime. The data obtained from BPS Padang and Metro Padang Pos newspaper specifically related to crime news. Media newspapers can also be used as a source in order to make observations related to the crime in Padang City. One of the daily newspapers that contains news on crime is Metro Padang Post newspaper. It is published every day with news headlines on the incidences of crime. The crime news contained in Metro Padang Post newspaper has its characteristics associated with the type of crime that occurs, the location, and the motives behind the occurrence of the crime. To analyze the data on the type of crime that has taken place and the characteristics of the area (the location of the crime), we used descriptive analysis techniques and analytical techniques focused on Geographic Information Systems (GIS). We used the available data on the rate of crime and the type of crime associated with the characteristics of an area. The results of the GIS analysis have then been presented in the form of a map. 


\section{Results and Discussion}

\section{The development of Padang City (population and economy)}

Padang city is a region with a population growth rate per year that is consistently increasing. Since 2011, the population growth had increased from $1.63 \%$ in 2011 to $1.54 \%$ in 2012 . In 2013, the population of Padang rose to 876,670 people (1.54\%). In 2014, it increased again to 889,561 people (1.47\%). In 2015, it increased to 902,413 people (1.44\%). In 2016, it rose again by $1.39 \%$ (Figures 1.).

The economic growth in West Sumatra Province from 2016 to 2017 amounted to 5.15\%. On the production side, the increase related to the field of information, and the communication business also grew by $9 \%$. The provision of accommodation grew by $8.58 \%$, and the sector food and beverages, as well as services, grew by $8.56 \%$. In terms of spending according to overseas exports, this grew by $24 \%$ (Badan Pusat Statistik 2017b). The economic growth, when it increased in West Sumatra, also affected the economic development that took place in Padang City. Padang city is the center of various activities such as economics, education, transportation, tourist areas, services, entertainment, culinary, and others. It is one factor outside of the public appeal to come to Padang City. In other words, the attractiveness of a region cannot be separated from the development of the area itself. It is associated with the theory of migration from suburban to urban areas. In urban areas, there is certainly an attraction that makes people come to the region. Mantra (2013) suggested that the migration process may occur due to individual factors, factors that related to the area of origin, the factors of the region of interest and obstacles in the area of origin compared to the destination. The increase in the available transportation and communication channels makes it easier for an individual to transplant themselves in the form of both permanent and non-permanent migration from a rural to an urban area. It has become one of the factors that can increase the population in urban areas. Samli (2012) said the change in the physical appearance of the city area is closely related to the rapid development of the urban population, followed by the development of the type and intensity of activities with all the facilities contained in the urban area.

\section{The development of criminality in Padang City}

An increase in the population, economic development, and public welfare has a positive impact on the development of a region. However, there is no doubt that this will also lead to adverse effects on the region. One negative impact concerning the population growth and economic development of a region is the crime level in urban areas. Based on the BPS data for 2014, 2015, 2016, 2017, and 2018 on crime in the jurisdiction of Padang City, Table 1 details the number of criminal offenses that have occurred in Padang between 2014 and 2018.

Although in some areas the South Padang Police and the Police of Koto Tangah and Padang are causing a decrease in the crime rate, it can be generally seen that there has been an increase in the amount of crime in several districts in Padang City. The decrease and increase in crime in Padang City is certainly not equal across the districts. In 2017-2018 in general, a few of the districts in Padang City have managed to decrease the amount of felonies that have occurred. The data regarding crime was not only obtained from BPS data. It also from the Metro Padang Post newspaper which contains news about the crimes committed in Padang City. Based on the news, one can determine the different types of crime that committed in the districts in Padang City. The newspaper contains information on the location, motives and losses involved.

Zuriyani and Despica (2017) suggested that Metro Padang Post newspaper is one of the print media outlets in Padang that contains a variety of information on the crime that has occurred in the region of West Sumatra and other regions in Indonesia. Each print media outlet has its traits that are associated with its respective overall message. Every day, newspapers carry stories about criminality in their headlines. This way, the public can find out about the crime that has happened in West Sumatra. Based on the data collected through a newspaper on crime, Pos Metro Padang, there were some areas in Padang with a high crime rate in 2015 and 2016; there are three categories of crime in Padang City; low, moderate, and high. 
Table 1.

Crime total in Padang 2014-2018

\begin{tabular}{|c|c|c|c|c|c|}
\hline \multirow{2}{*}{ District } & \multicolumn{5}{|c|}{ Crime total } \\
\hline & 2014 & 2015 & 2016 & 2017 & 2018 \\
\hline Polresta Padang & 1725 & 1927 & 1411 & 1831 & 1173 \\
\hline Polsekta Kawasan & 54 & 43 & 34 & 19 & 5 \\
\hline Polsekta Bungus Teluk Kabung & 81 & 78 & 77 & 72 & 43 \\
\hline Polsekta Lubuk Kilangan & 396 & 367 & 361 & 309 & 158 \\
\hline Polsekta Lubuk Begalung & 595 & 599 & 615 & 529 & 230 \\
\hline Polsekta South Padang & 467 & 502 & 477 & 300 & 141 \\
\hline Polsekta East Padang & 380 & 369 & 690 & 682 & 248 \\
\hline Polsekta West Padang & 627 & 607 & 614 & 636 & 271 \\
\hline Polsekta North Padang & 754 & 722 & 742 & 674 & 300 \\
\hline Polsekta Nanggalo & 507 & 488 & 463 & 431 & 186 \\
\hline Polsekta Kuranji & 686 & 760 & 792 & 698 & 299 \\
\hline Polsekta Pauh & 333 & 434 & 466 & 449 & 213 \\
\hline Polsekta Koto Tangah & 1022 & 957 & 812 & 884 & 443 \\
\hline Total & 7627 & 7853 & 7554 & 7577 & 3710 \\
\hline \multicolumn{6}{|c|}{$\begin{array}{l}\text { Notes: } \\
\text { Polresta or Kepolisian Resor Kota or City Resort Police } \\
\text { Polsekta or Kepolisian Sektor Kota or City Sector Police }\end{array}$} \\
\hline \multicolumn{6}{|c|}{ Source: Badan Pusat Statistik (2020) } \\
\hline
\end{tabular}

Table 2 shows that the areas with the highest crime rate were West Padang, South Padang, and Lubuk Begalung in 2015. In 2016, Kuranji, West Padang, East Padang, and South Padang, Koto Tangah, were the areas with a high crime rate in Padang. Setiawan and Dona (2015) said that the crime rate could be measured by the level of social welfare and the risk of crime. In other words, every society is at risk of becoming a victim of crime. The more often that people experience crime, the more that the region can be said to be increasingly unsafe. 2015-2016 can be used to determine that the regions of West Padang, South Padang, Lubuk Begalung, East Padang, Koto Tangah, and Kuranji were unsafe areas.

After determining the crime rate of each sub-district in Padang, further types of crime can be observed as taking place in Padang City using the data from the Metro Padang Post newspaper. The criteria for the type of crime related to the target of a crime such as people, property, public order, the state, etc. In addition, the severity of the crime (crimes against life, crimes against the physical body, crimes against property or goods, etc.) also a criterion when classifying the type of crime. Crimes against a person's rights, crimes related to the use of violence, crimes against property or goods without violence, etc. were also included in the classification of crime. Simamora and Ratnasari (2014) explained that each region would have particular spatial or geographic characteristics that can also cause difference-attachment factors that refer to economics, social qualities, and culture. Regression involves the influence of the variable density and the percentage of the migrant population as the factors related to geographical weight that tied to the occurrence of criminal acts.

Badan Pusat Statistik (2016b) explained in Criminal Law Book or Kitab Undang-Undang Hukum Pidana (KUHP) Republic of Indonesia and The International Classification of Crime for Statistical Purposes (ICCS) that there are several classifications of crime: crimes against life (murder), crimes against the physical (light maltreatment, aggravated assault, and domestic violence), crimes against morals (rape and sexual abuse), crimes against personal liberty (kidnapping and employing minors), crimes against property rights through the use of violence (theft with violence and the use of weapons), crimes against property or goods (theft by weighting, motor vehicle theft, the destruction of goods, burning with weapons and fencing), drug-related crime and psychotropic, crimes related to fraud, embezzlement and corruption, and crimes against public order. 
Table 2.

Categories of Crime Rate

\begin{tabular}{|c|c|c|}
\hline Category & $\begin{array}{c}2015 \\
\text { (Sub-district) }\end{array}$ & $\begin{array}{c}2016 \\
\text { (Sub-district) }\end{array}$ \\
\hline Low & $\begin{array}{l}\text { Nanggalo, Lubuk Kilangan, Bungus Teluk } \\
\text { Kabung, Pauh }\end{array}$ & $\begin{array}{l}\text { Nanggalo, Bungus Teluk Kabung, } \\
\text { Lubuk Begalung }\end{array}$ \\
\hline Moderate & $\begin{array}{l}\text { Kuranji, East Padang, Koto Tangah, } \\
\text { North Padang }\end{array}$ & Lubuk Kilangan, Pauh, North Padang \\
\hline High & $\begin{array}{l}\text { West Padang, South Padang, Lubuk } \\
\text { Begalung }\end{array}$ & $\begin{array}{l}\text { Kuranji, West Padang, South } \\
\text { Padang, East Padang, Koto Tangah }\end{array}$ \\
\hline
\end{tabular}

Source: Zuriyani \& Despica 2017

Table 3.

Number and types of crime in Padang City in 2015-2016 according to Metro News Padang newspaper

\begin{tabular}{lcl}
\hline \multicolumn{1}{c}{ Location } & \multicolumn{1}{c}{ Crime Types } \\
\hline \multicolumn{1}{c}{ (Sub-district) } & Amount & \multicolumn{1}{c}{ Type } \\
\hline Bungus Teluk Kabung & 20 & Murder, wanton, theft and narcotics \\
Koto Tangah & 67 & Murder, wanton, theft and narcotics and gambling \\
Kuranji & 46 & Murder, wanton, theft and narcotics, gambling and fraud \\
Lubuk Kilangan & 30 & Murder, wanton, theft and narcotics, gambling and fraud \\
Lubuk Begalung & 49 & Murder, wanton, theft and narcotics and gambling \\
Nanggalo & 23 & Murder, wanton, theft and narcotics, gambling and fraud \\
South Padang & 74 & Murder, wanton, theft and narcotics, gambling and fraud \\
West Padang & 105 & Murder, wanton, theft and narcotics, gambling and fraud \\
East Padang & 67 & Murder, wanton, theft and narcotics, gambling and fraud \\
North Padang & 47 & Murder, wanton, theft and narcotics, gambling and fraud \\
Pauh & 19 & Murder, wanton, theft and narcotics, gambling \\
\hline Total & 547 & Murder, wanton, theft and narcotics \\
\hline
\end{tabular}

From the data that collected on the types of crime in each district, there found to be many different kinds of criminality, as detailed by Metro Padang newspaper. The crimes related to narcotics, drugs, theft, and immoral acts were the most dominant types of crime that occurred in every district in Padang City. Below is a table on the dominant crimes that occurred per district and their respective frequency.

In the sub-district of Bungus Teluk Kabung, the dominant crimes that occurred were narcotics and immoral acts. In the Koto Tangah, Kuranji, Kilangan, Lubuk Begalung, Nanggalo, South Padang, East Padang, and North Padang sub-districts, the dominant types of crime were theft with violence, theft with a weapon, theft without violence, theft without a weapon and narcotics. Meanwhile, in the District of West Padang, the dominant types of crime were theft with violence, theft with a weapon, theft without violence, theft without a weapon, narcotics, and immoral acts.

In Diagram 1 for West Padang, there were three types of crimes that were dominant, namely theft, narcotics and immoral acts with nearly the same incidence rate. The West area is a region of Padang District that is an activity center and downtown area. In this region, there are many centers of economic activity, trade, entertainment and other attractions. The variety of the activities and attractions available automatically make the movement of people more increased into the region. The attractiveness of the region can have both positive and negative impacts. One of the negative impacts is the emergence of criminality in centers such as the market areas. In addition to West Padang, in the subdistrict of Koto Tangah, theft was the dominant type of crime. Further south, in East Padang and Lubuk Begalung, the most common type of crime is also theft. Based on the data from the 
Badan Pusat Statistik (2015), theft was the most common crime with theft weighted at $31.44 \%$. Stealing motorcycles amounted to $20.90 \%$ and theft with violence amounted to $21.39 \%$. In general, the problem of theft is still the dominant criminal act in urban areas. According to Feriansyah (2014), stealing motorcycles, drunkenness and theft are the crimes often done by teenagers.

Table 4.

The most dominant types crime in Padang City in 2015-2016

\begin{tabular}{lccc}
\hline Sub-district & \multicolumn{3}{c}{ Dominant crime type } \\
\cline { 2 - 5 } & $\begin{array}{c}\text { Theft with violence, } \\
\text { theft with a weapon, } \\
\text { theft without violence, } \\
\text { theft without weapons }\end{array}$ & $\begin{array}{c}\text { Narcotics, } \\
\text { psychotropic }\end{array}$ & $\begin{array}{c}\text { Rape, } \\
\text { molestation } \\
\text { (immoral) }\end{array}$ \\
\hline Bungus Teluk Kabung & $\sqrt{ }$ & $\sqrt{ }$ & $\sqrt{ }$ \\
Koto Tangah & $\sqrt{ }$ & $\sqrt{ }$ & \\
Kuranji & $\sqrt{ }$ & $\sqrt{ }$ & \\
Lubuk Kilangan & $\sqrt{ }$ & $\sqrt{ }$ & \\
Lubuk Begalung & $\sqrt{ }$ & $\sqrt{ }$ & \\
Naggalo & $\sqrt{ }$ & $\sqrt{ }$ & \\
South Padang & $\sqrt{ }$ & $\sqrt{ }$ & \\
West Padang & $\sqrt{ }$ & $\sqrt{ }$ & $\sqrt{ }$ \\
East Padang & $\sqrt{ }$ & $\sqrt{ }$ & \\
North Padang & & & \\
Pauh & & &
\end{tabular}

Source: Primary data analysis results (2017)

In addition to theft, acts of wanton violence and narcotics are also among the dominant crimes occurring in Padang City. Wanton criminality is associated with the crimes that occur involving women such as rape, violence against women and sexual harassment. According to Koranti and Purwani (2014), in Indonesia, crimes against women are at a critical level or in the moderate category based on the annual report on trafficking organized by the US Domestic Department. Besides the issue of being sacrilegious, drug problems are a serious crime with a dominant place in Padang City. Despite the efforts of both national and international institutions, a large number of drugs are produced, trafficked and consumed by many people. Transnational crime syndicates generate new psychoactive substances when the government tries to increase their control over the existing drugs. The annual number of drug-related deaths has risen to 250.000 worldwide.

The widespread circulation of illegal drugs cannot be separated from the impact of globalization, technology and developments in the field of transport and communications. Business information makes it easier for drug smuggling to happen to other countries, including Indonesia. In addition to the strategic geographical location that serves the area of production and distribution, it is also a transit area for narcotics and poverty. The social and political situation is not stable so it can be exploited by the narcotics dealers (Ramadhani 2016). Globalization has changed the global economy. Forty years of spreading ideas and technology across the borders between countries has occurred rapidly. This facilitates new trade channels, new markets and expansion. In a world of free trade, a country can access goods from all over the world. This is the good side of globalization. However, there is also the bad side of globalization. There has been an emergence of a network of black markets ranging from drugs and arms trafficking to people who are smuggled into slavery and prostitution. These consist of some of the most severe problems for all people as the crimes endanger the safety and security of both property and people (Jenner 2011). Harian Haluan (2016) stated that Padang City is already in a state of emergency because of drug use. The transport lines in place facilitate the movement of drugs into Padang City. Officers from Sat Resnarkoba Padang have revealed that the movement of drugs dealers from neighboring Malaysia into the Pekanbaru region then continues into Bukittinggi. The drugs can then be deployed to several areas including Padang City. 


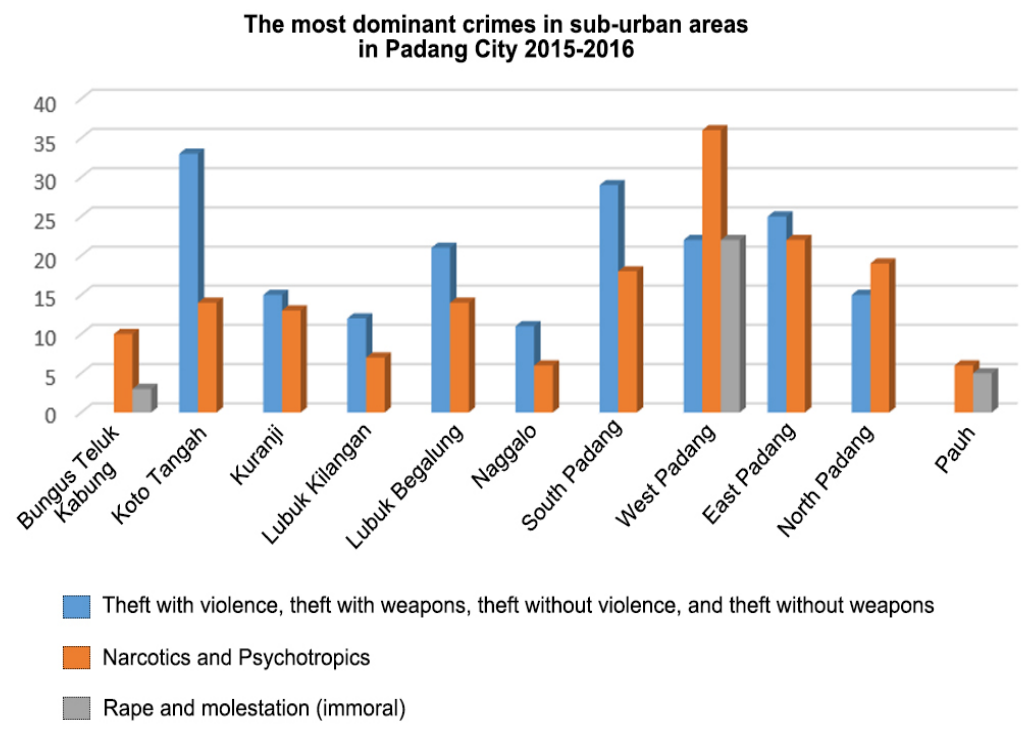

Diagram 1.

Dominant crimes sub-urban area in Padang City in 2015-2016

\section{Linkage development between urban areas and crime}

According to Figure 1 on the dominant types of crime that have occurred in Padang using a city map (2015-2016), the highest crime rate was in the downtown area in the districts of West Padang, South Padang, and East Padang. The characteristics of these three areas are that there are a variety of facilities and activity centers. It has resulted in an increased number of people moving to the central region. The area is also a center for the economy, society, educational centers, shopping centers, the provincial government center, facilities, and infrastructure that focused on tourism and entertainment. The transportation infrastructure allowed people from other regions to move to this area, so the chance of committing a crime is also now more likely to occur in this region.

In Table 5, there is a link between the developments region and the amount of crime occurring in the urban areas. According to Nugrahandika, Ramadani, and Nurfajrina (2018), crime in urban areas associated with road patterns, environment, and service facilities such as the schools, residential, and crowd levels based on their proximity to roads and the maintenance of the environment. It is in addition to the social inequality present. After the calculation of the development of the region based on the indicators of population density, education, health facilities, load dependency, the number of pre-prosperous families as well as the characteristics of the territory of each district, it found that Lubuk Begalung, East Padang district, West Padang district, North Padang, Koto Tangah and Nanggalo were the regions with the highest level of development. It characterized by a high population density, good accessibility to adequate health care, and a decent number of education facilities. According to the research, an area with a high level of growth also has a high crime rate, as in Lubuk Begalung, West Padang, and Koto Tangah subdistricts. North Padang has a moderate crime rate, and East Padang and Nanggalo have a low crime rate. The indicators of the socio-economic factor are well-aligned with the level of criminality in the region. According to Oliver (2002), the education factor has a close relationship (that is significant) with the occurrence of crime.

Meanwhile, the income factor also has a significant relationship with criminality (Machin \& Meghir 2004). Tabar and Noghani (2019) mentioned that from 2005 to 2013, there found to be a significant relationship between unemployment and crime. Developing countries have a higher crime rate that is often associated with the economic level present. Purwanti \& Widyaningsih (2019) explained that the level of unemployment had a significant effect on the crime rate between 2007 and 2012 on the island of Java. It is because found to be associated with a high population level. 


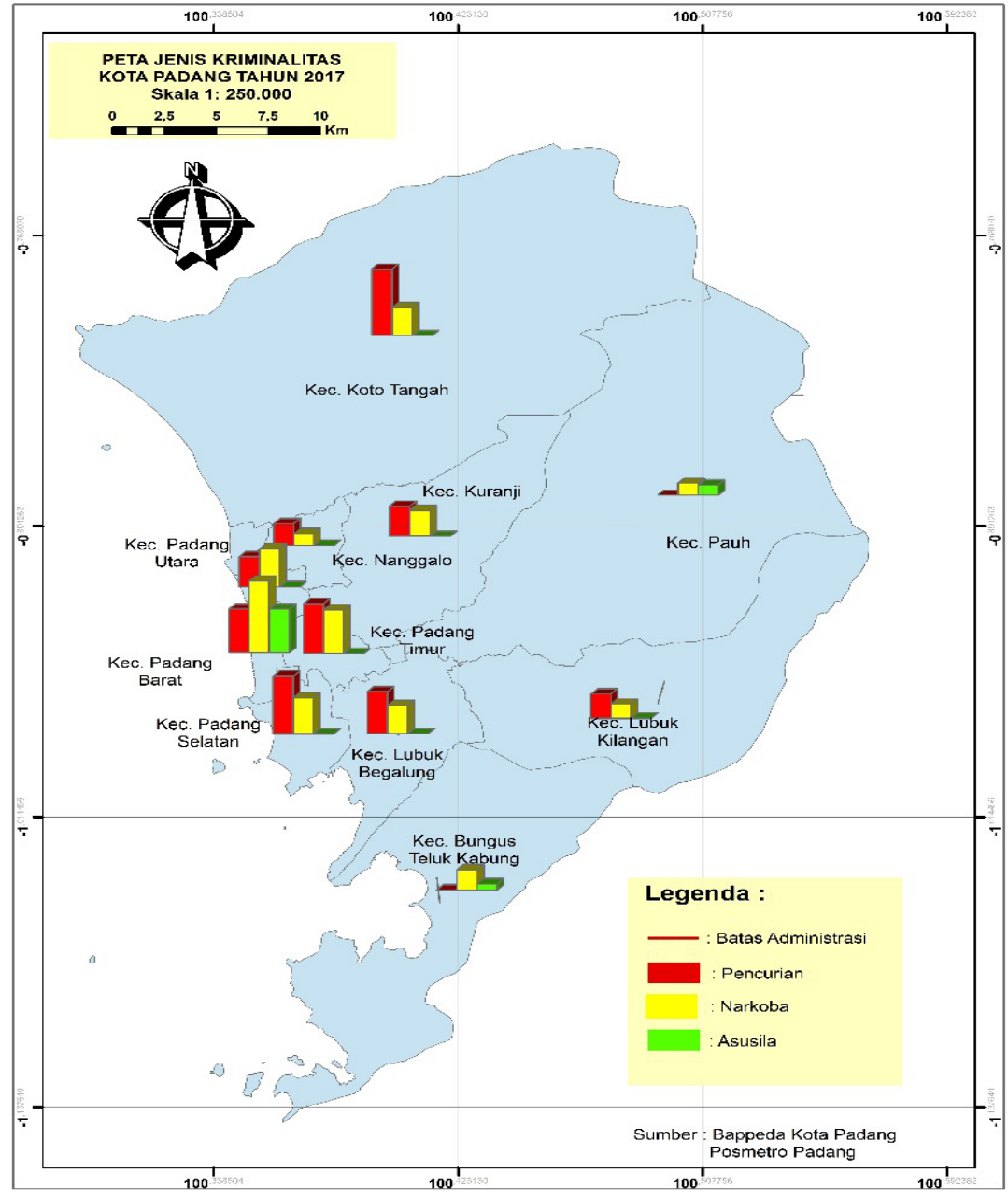

Figure 1.

The dominant types of crime in Padang City using a map (2015-2016)

Based on the characteristics of the region, the West area was Padang District's downtown. Koto Tangah sub-district is a suburban area bordered by the Lubuk Begalung. This is connected to the other jurisdictions adjacent to the area. Koto Tangah is adjacent to Padang Pariaman and it is the gateway to Padang City relating to the movement of people coming from the districts of Padang Pariaman, Bukittinggi, Agam regency, Tanah Datar and the outer provinces such as Riau, Medan and Java Island. The transportation path is often through the air because it is close to the international airport, Minangkabau. Lubuk Begalung is a region that will be passed through due to the movement of people coming from Solok district and the south coast and other provinces such as Jambi, South Sumatra, Lampung and Java. The characteristics of the areas of Koto Tangah and Lubuk Begalung are that they are directly adjacent to the other areas mentioned. This affects the movement of people from these areas, as conveyed by Choa and Ho (2018). The diversity of the communities located in the urban areas will affect a person's actions and even influence criminal behavior, especially if it is related to the socioeconomic circumstances in society.

In line with the theory of urbanization in urban areas, Harahap (2013) argued that urbanization had caused many problems in Indonesia, especially in big cities, such as an increase in the level of poverty, the presence of slums, and an increased rate of urban crime. Urbanization is influenced by the differences in growth or uneven development, particularly between the rural and urban areas. As a result, the urban areas become a magnet for the suburban community, and people from outside of the region or town thus come to the urban areas. The increasing population in urban areas correlates with the increasing urbanization of the region. Areas with a high level of economic activity have a high rate of population contrast. The convergence of social activity, economic activity, and other services in urban areas leads to several positive impacts and social problems, including crime. It was stated by 
Latief, Usmita, and Novarizal (2017) in their research. They put forward that urbanization affects the emergence of social problems. With so many events of crime taking place, it indicates that the conditions are suggestive of a relatively low level of social welfare. In line with what was mentioned by Hendri (2014), the unevenness of the region is one of the important factors that influence the crime rate.

Table 5.

Linkage development with the development of the crime rate in Padang City

\begin{tabular}{|c|c|c|c|c|c|c|c|c|c|}
\hline \multirow[b]{2}{*}{$\begin{array}{l}\text { Sub- } \\
\text { district }\end{array}$} & \multicolumn{6}{|c|}{ Regional development indicators } & \multirow[b]{2}{*}{$\begin{array}{l}\text { Characteristic } \\
\text { of the region }\end{array}$} & \multirow[b]{2}{*}{$\begin{array}{c}\text { Rate } \\
\text { level } \\
\text { by } \\
\text { region }\end{array}$} & \multirow[b]{2}{*}{$\begin{array}{c}\text { Crime } \\
\text { level } \\
(2015- \\
2016)\end{array}$} \\
\hline & $\begin{array}{c}\text { Population } \\
\text { density } \\
\text { (people/ } \\
\text { km) }\end{array}$ & $\begin{array}{l}\text { Accessibility } \\
\text { area (length } \\
\text { in } \mathbf{k m})\end{array}$ & $\begin{array}{c}\text { Total } \\
\text { education } \\
\text { facility }\end{array}$ & $\begin{array}{c}\text { Total } \\
\text { healthy } \\
\text { facility }\end{array}$ & $\begin{array}{c}\text { Figure } \\
\text { charges } \\
\text { amenability } \\
\text { (dependency } \\
\text { ratio) }\end{array}$ & $\begin{array}{c}\text { The } \\
\text { number } \\
\text { of pre- } \\
\text { prosperous } \\
\text { families } \\
\text { and } \\
\text { prosperous } \\
\text { families I } \\
\text { and II }\end{array}$ & & & \\
\hline $\begin{array}{l}\text { Bungus } \\
\text { Teluk } \\
\text { Kabung }\end{array}$ & 247 & 140.96 & 25 & 42 & 53.18 & 2802 & $\begin{array}{l}\text { Padang } \\
\text { suburb } \\
\text { border with } \\
\text { the South } \\
\text { Coastal } \\
\text { District }\end{array}$ & Low & Low \\
\hline $\begin{array}{l}\text { Lubuk } \\
\text { Begalung }\end{array}$ & 3923 & 362.72 & 86 & 122 & 44.41 & 4762 & $\begin{array}{c}\text { Suburb of } \\
\text { Padang City }\end{array}$ & High & High \\
\hline $\begin{array}{l}\text { South } \\
\text { Padang }\end{array}$ & 5957 & 172.46 & 81 & 82 & 47.62 & 4957 & $\begin{array}{c}\text { Suburb of } \\
\text { Padang City }\end{array}$ & $\begin{array}{l}\text { Mod- } \\
\text { erate }\end{array}$ & High \\
\hline $\begin{array}{l}\text { East } \\
\text { Padang }\end{array}$ & 9751 & 294.76 & 102 & 102 & 43.86 & 11551 & $\begin{array}{c}\text { Padang City } \\
\text { Center }\end{array}$ & High & Low \\
\hline Kuranji & 2555 & 617.68 & 107 & 92 & 38.87 & 6564 & $\begin{array}{l}\text { Closest } \\
\text { to the } \\
\text { downtown } \\
\text { area, partly } \\
\text { including the } \\
\text { suburbs }\end{array}$ & $\begin{array}{l}\text { Mod- } \\
\text { erate }\end{array}$ & High \\
\hline Pauh & 492 & 361.5 & 49 & 81 & 29.55 & 10074 & $\begin{array}{c}\text { Suburb of } \\
\text { Padang City }\end{array}$ & $\begin{array}{l}\text { Mod- } \\
\text { erate }\end{array}$ & $\begin{array}{l}\text { Moder- } \\
\text { ate }\end{array}$ \\
\hline $\begin{array}{l}\text { Koto } \\
\text { Tangah }\end{array}$ & 817 & 1070.28 & 173 & 101 & 39.55 & 12568 & $\begin{array}{c}\text { Suburb of } \\
\text { Padang City, } \\
\text { Padang } \\
\text { Pariaman } \\
\text { regency }\end{array}$ & High & High \\
\hline
\end{tabular}

Source: Badan Pusat Statistik 2016-2017a and the research data from 2016 (secondary data analysis results in 2017)

\section{Conclusion}

In 2015-2016, there were five districts with a high crime rate: West Padang, South Padang, Lubuk Begalung, Kuranji, and Koto Tangah. Based on the indicators of population density, accessibility, education facilities, health facilities, the dependency load and the number of pre-prosperous families, a region with a high development rate often has a high crime rate, as seen in Lubuk Begalung district, the subdistrict of West Padang and Koto Tangah. The three types of crimes that found to 
be dominant in Padang City were theft with violence or theft with a weapon, theft without violence or theft without weapons, narcotics, and immoral acts. The characteristics of the areas with a high crime rate in the downtown area are different from the areas with both small and large populations, respectively. However, both had a high level of economic activity. Meanwhile, other suburban areas act as a gateway to Padang City, which means that more people can move through the region. There is a link between the development of the region with the crime occurring in the urban areas. The transportation infrastructure also allows people from other areas to move freely. It means that the chance of committing a crime is also more likely to occur in this region.

\section{References}

Badan Pusat Statistik (2015) Padang dalam Angka Tahun 2015. Badan Pusat Statistik Kota Padang. [Accessed 1 September 2017]. https://padangkota.bps.go.id/publication/2016/02/18/701cd3 48248e88c03225b381/kota-padang-dalam-angka-2015.html.

Badan Pusat Statistik (2016a) Padang dalam Angka Tahun 2016. Badan Pusat Statistik Kota Padang. [Accessed 2 September 2017]. https://padangkota.bps.go.id/publication/2016/07/15/4e3006 466268af92b7bee727/kota-padang-dalam-angka-2016.html.

Badan Pusat Statistik (2016b) Statistik Ketahanan Sosial Sumatera Barat 2016. Badan Pusat Statistik Provinsi Sumatera Barat. [Accessed 2 September 2017]. https://sumbar.bps.go.id/ publication/2017/12/27/a9fd08788cd4499b105c3131/statistik-ketahanan-sosial-sumaterabarat-2016.html.

Badan Pusat Statistik (2017a) Indikator Kesejahteraan Rakyat Provinsi Sumatera Barat 2017. Badan Pusat Statistik Provinsi Sumatera Barat. [Accessed 2 September 2017]. https://sumbar.bps. go.id/publication/2018/11/28/eb51f8f3657da01 abeed1591/indikator-kesejahteraan-rakyatprovinsi-sumatera-barat-2017.html.

Badan Pusat Statistik (2017b) Padang Dalam Angka Tahun 2017. Badan Pusat Statistik Kota Padang. [Accessed 3 September 2017]. https://padangkota.bps.go.id/publication/2017/08/10/40ffc9 17a4dc6a6383c24b76/kota-padang-dalam-angka-2017.html.

Badan Pusat Statistik (2020) Jumlah Tindak Pidana Menurut Kepolisian Resort di Kota Padang 2014-2018. [Accessed 30 Januari 2020]. https://padangkota.bps.go.id/dynamic table/2017/07/10/114/jumlah-tindak-pidana-menurut-kepolisian-resort-di-kota-padang -2014-2018-.html.

Choa W \& Ho AT (2018) Does neighborhood crime matter? A multi-year survey study on perceptions of race, victimization, and public safety. International Journal of Law, Crime and Justice 55:13-26. https://doi.org/10.1016/j.ijlcj.2018.08.002.

Feriansyah (2014) Faktor-faktor penyebab meningkatnya kejahatan pencurian oleh remaja di Kota Singkawang ditinjau dari sudut kriminologi. E-Journal Gloria Yuris 3 (1).

Harahap F (2013) Dampak urbanisasi bagi perkembangan kota di Indonesia. Jurnal Society 1 (1):3545. https://doi.org/10.33019/society.v1i1.40.

Harian Haluan (2016) Kasus Narkoba Meningkat Tajam di Kota Padang. [Accessed 16 December 2017]. https://www.harianhaluan.com/news/detail/46674/kasus-narkoba-meningkat-tajamdi-kota-padang.

Hendri D (2014). Kriminalitas: Sebuah sisi gelap dari ketimpangan distribusi pendapatan. Jurnal Ekonomi dan Kebijakan Publik 5 (2):239-252.

Jenner MS (2011) International drug trafficking: A global problem with a domestic solution. Indiana Journal of Global Legal Studies 18 (2):901-907.

Koranti K \& Purwani W (2014) Kajian sosial-ekonomi dalam menganalisis faktor penyebab tindak kriminal terhadap wanita di era globalisasi. In: $3^{\text {rd }}$ Economics and Bussines Research Festival Proceeding Seminar \& Call for Papers: Business Dynamics Toward Competitive Economic Region of Asean, 13 Nov 2014. Salatiga: Universitas Kristen Satya Wacana, 881-898.

Latief SA, Usmita F, \& Novarizal R (2017) Trend kriminal di Pekanbaru 2012-2016. Sisi Lain Realita 2 (1):1-19. https://doi.org/10.25299/sisilainrealita.2017.vol2(1).1381. 
Mantra IB (2013) Demografi Umum Edisi Kedua. Yogyakarta: Pustaka Pelajar.

Machin S \& Meghir C (2004) Crime and economic incentives. The Journal of Human Resources 39 (4):958-979.

Nugrahandika WH, Ramadhani R \& Nurfajrina IA (2018) Karakteristik kriminalitas di kawasan permukiman (Studi Kasus: Perumahan dan Kampung Kabupaten Sleman). Plano Madani 7 (2):209-220.

Oliver A (2002) The economic of crime: An analysis of crime rates in America. The Park Place Economist 10 (1):30-35. https://digitalcommons.iwu.edu/parkplace/vol10/iss1/13.

Purwanti EY \& Widyaningsih E (2019) Analisis faktor ekonomi yang mempengaruhi kriminalitas di Jawa Timur. Jurnal Ekonomi-Qu 9 (2):154-177.

Punaji S (2010) Metode Penelitian Pendidikan dan Pengembangan. Jakarta: Kencana.

Ramadhani H \& Waluyo TJ (2016) Kebijakan Asean senior officials on drugs matters (ASOD) menanggulangi drugs trafficking di Indonesia (2009-2013). Jurnal Online Mahasiswa Fisip $3(1): 1-10$.

Samli A (2012) Analisis pengembangan kota berdasarkan kondisi fisik wilayah Kota Masohi Ibukota Kabupaten Maluku Tengah. Jurnal Plano Madani 2 (1):74-85.

Setiawan \& Dona FM (2015) Pemodelan faktor-faktor yang mempengaruhi tingkat kriminalitas di Jawa Timur dengan analisis regresi spasial. Jurnal Sains \& Seni ITS 4 (1).

Simamora PA \& Ratnasari V (2014) Pemodelan persentase kriminalitas dan faktor-faktor yang mempengaruhi di Jawa Timur dengan pendekatan Geographically Weighted Regression (GWR). Jurnal Sains \& Seni ITS 3 (1):2337-3520.

Sugiyono (2013) Metodologi Penelitian Kuantitatif, Kualitatif dan R\&D. Bandung: ALFABETA.

Tabar \& Noghani (2019) Unemployment and crime in developing countries: A meta-analysis in Iran. Crime Law Soc Change 72 (3):327-338. https://doi.org/10.1007/s10611-019-09823-y.

Yuliandarmaji A (2013) Analisis spatio-temporal kriminalitas Kota Yogyakarta dengan visualisasi webgis tahun 2011-2012. Jurnal Publikasi Ilmiah 1-13.

Zuriyani E \& Despica R (2017) Utilization of Pos Metro Padang newspaper for spatial analysis of crimes rate in urban area (case study of crimes rate in Padang City from 2015-2016). In: International Conference on Culture, Art, and Humanities Universitas Andalas. Padang: Universitas Andalas, 108-117. 